\title{
YIELD AND YIELD COMPONENT ASSOCIATION OF SOME CAPSICUM GENOTYPES
}

\author{
G. A. IWO, J. D. NTIA AND E. G. AKPANIWO \\ (Received 24 July 2015; Revision Accepted 26 August 2015)
}

\begin{abstract}
The experiment was conducted in humid agro ecological zone of Calabar, Nigeria, to evaluate the yield performance and the association between yield and yield related components of some capsicum genotypes which include; Bird pepper(Capsicum annuumvar. aviculare), Habanero pepper(Capsicum chinense), Thai pepper(Capsicum annuum var.glabriusculum),Tabasco pepper(Capsicum frutescens) and Bell pepper(Capsicum annuum. Var.accuminatum). Randomized complete block design was used for the experiment, planted in all three replications. The result showed that all the genotypes of pepper used were significantly different $(P=O .05)$ in plant height, number of branches, fruit length, fruit breadth, number of fruit per plant and total fruit yield but no significant differences was observed in days to $50 \%$ flowering and leaf area. The cultivar Tabasco pepper gave the highest yield of $2426.66 \mathrm{~kg} / \mathrm{ha}$ followed by bird pepper with a total yield of $2239.99 \mathrm{~kg} / \mathrm{ha}$ while the cultivar Hebanero pepper gave yield of $1907 \mathrm{~kg} / \mathrm{ha}$. The least yield was recorded on Thai pepper with $1520 \mathrm{Kg} / \mathrm{ha}$ and bell pepper gave $1680 \mathrm{~kg} / \mathrm{ha}$. The linear correlation analysis of the yield and yield related component revealed that days to $50 \%$ flowering $(r=0.613)$, fruit length $(r=0.392)$, number of branches $(r=0.913)$, number of fruits per plant $(r=0.422)$ and plant height $(r=0.424)$ showed positive relationship with fruit yield. The yield component with positive and significant correlation can be used as selection indices for the improvement of capsicum species
\end{abstract}

KEYWORDS: Components, Correlation, Genotypes, Pepper, Yield.

\section{INTRODUCTION}

The genus Capsicum also known as pepper is an annual shrub with many branches belonging to the family Solanaceae. It is one of the most important vegetables grown in Nigeria and other parts of humid and semi-arid tropics (Aliyu 2000). The crop thrives best in relatively warm climate, in well drained, sandy loam soil. Hot and dry weather is desirable for fruit ripen and drying. Pepper is used in all kinds of cookery as pungent species. It is also used in seasoning sauces, soup and other dishes. It has medicinal properties used in prevention and treatment of cold and fever (Udoh et. al 2005). Pepper like other vegetable crops contributes nutritiously in nutrients that may be lacking in other food materials (Grubben 1997). Therefore the potential uses to human cover large area such as food and nutrition, medicinal value, plant based insecticides and income generation (Dagnoko et al 2013). According to Aguisiobu (2002), Kehinro and Ketiku (2004), pepper is rich sources of vitamin A and Vitamin C. The fruit can be dried, ground to powder and use as ingredient in curry powder (Dewitt and Bosland 2009).

World production of pepper is estimated at 2.4 million tons harvested from 1.65 million hectares giving an average yield of 1.4 tons/ha (FAO, 2005). In Nigeria, pepper is very important and widely cultivated in every part of the Country. But the constraint is that yield per hectare is still very low when compared with other crops. According to Idowu et al (2012) about 200 selections of pepper are in Nigeria. Therefore, there is need to improve on the yield of the available cultivars considering the yield components. The absolute capacity of pepper to produce economic yield under optimum production condition depends on the genetic constitution of the crop and the inherent physiological activities which involved in their formation, interaction of the growth environment, management practice and pest control. Yield being an important attribute in the production of pepper, is influenced by both growth and yield characters. Therefore, there is need to evaluate the magnitude and nature of the association between yield and the related yield characters. The purpose of this study therefore is to evaluate the yield performance and association between the yield and related yield components.

\section{MATERIALS AND METHODS}

The experiment was conducted at the University of Calabar Research and Teaching farm. Calabar is located in the tropical rainforest ecological zone of Nigeria. At Latitude $4^{0} 96$ ' $\mathrm{N}$ of the equator and longitude $8^{0} 31^{\prime} \mathrm{E}$ with bimodal annual rainfall ranges from $2000 \mathrm{~mm}$ to $3000 \mathrm{~mm}$ from April to November. Five genotypes of capsicum were obtained from the

G. A. Iwo, Department of Crop Science, University of Calabar, P.M.B 1115, Calabar, Cross River State, Nigeria.

J. D. Ntia, Department of Crop Science, University of Calabar, P.M.B 1115, Calabar, Cross River State, Nigeria.

E. G. Akpaniwo, Department of Crop Science, University of Calabar, P.M.B 1115, Calabar, Cross River State, Nigeria 
Agricultural Development Programme (ADP) Calabar. These were classified into three species; Capsicum annuum, Capsicum chinense, and Capsicum frustescens.

The land was cleared and nursery bed prepared for sowing of the seeds and this was allowed to grow for 45 days after which the plants were transplanted to the main seed beds.

The experiment was laid in a randomized complete block design (RCBD). Each genotype was sowed in $5 \mathrm{~m} \mathrm{X} 1.5 \mathrm{~m}\left(7.5 \mathrm{~m}^{2}\right)$ plot with inter - row spacing of $75 \mathrm{~cm}$ and intra - row spacing of $30 \mathrm{~cm}$ respectively, maintaining two plants per stand in three replications.

All cultural practices such as weeding were carried out at three weeks after transplanting and N.P.K. fertilizer application( $50 \mathrm{KgN}: 30 \mathrm{KgP}: 15 \mathrm{KgK})$ after the first weeding operation. Data were collected on plant height, number of branches, leaf area, number of capsules / plant, capsule length, capsule breadth and total fruit yield. The data analyses were carried out using the analysis of variance (ANOVA) and linear correlation analysis suggested by Singh and Chandhary (1980)

\section{RESULTS AND DISCUSSION}

The results of the field evaluation of five capsicum genotypes for yield performance and association with yield related components are presented in table 1. Combine analysis of variance showed high significant differences at $\mathrm{P}=0.05$ among the investigated capsicum genotypes considering all the evaluated yield components except days to $50 \%$ flowering and leaf area. High significant differences at $P$ $=0.05$ in plant characters within a population suggests the existence of sufficient variability upon which selection for improvement in these characters can be based (Amadi et al, 2008). The mean performances of the genotypes shows a clear indication of agronomic superiority of genotypes over others such as Tabasco pepper(Capsicum frutescens) with fruit yield of $2,426.6 \mathrm{~kg} / \mathrm{ha}$ and Bird pepper(Capsicum annuum) with yield of $2,239.9 \mathrm{~kg} / \mathrm{ha}$. Yield is a complex character associated with many interrelated components (Murat and Vehdettin 2004) but this could easily be estimated on the basis of the contribution of yield components and other closely associated characters of the capsicum species.

The result of the linear correlation analysis carried out between the yield components and yield are presented in table 2. The yield components; Days to $50 \%$ flowering $(r=0.613)$, fruit length $(r=0.392)$, leaf area $(r=0.067)$, number of branches $(r=0.913)$, number of fruit per plant $(r=0.422)$, and plant height $(r=0.424)$ showed positive relationship with fruit yield except the fruit breadth that correlated negatively with yield. These result indicated that days to $50 \%$ flowering, number of branches, fruit length, leaf area, plant height and number of fruit per plant of the pepper genotypes have positive and direct significant effect on yield. Negative and non-significant correlation was observed on fruit breadth with $r=-0.395$

The direct and positive association of these yield components can be used to develop an optimally reliable selection index for the improvement of fruit yield in capsicum species. This result confirmed the earlier studies by Hosamani and Shivkumar (2006), Ganeshreddet. al (2008), and Honya (1981). Association of plant character has always been helpful as a basis of selecting desire genotypes. The result suggested that pepper yield can be increased by improving the number of branches per plant, number of fruits per plant and leaf area due to the strong association with yield. According to Islam et.al (2008), Iwo and Ekaette (2010) selection pressure is exercised for improvement of any character highly associated with yield, and it simultaneously affects a number of other correlated traits. Hence, the knowledge regarding association of character with yield provides a guideline to the breeder for making improvement through selection.

\section{CONCLUSION}

Field performance of the evaluated pepper genotypes revealed significant variation in yield among the genotypes. Most of the yield related traits correlated positively with yield such as number of branches, number of fruits per plants, and fruit length . The positive association of some of the components with yield indicated possible use of these characters as reliable selection indices when considering these traits in pepper improvement.

TABLE 1: MEAN YIELD VALUES OF THE FIVE PEPPER GENOT

\begin{tabular}{lllllllll}
\hline GENOTYPES & $\begin{array}{l}\text { DAYS TO } \\
50 \% \\
\text { FLOWERING }\end{array}$ & $\begin{array}{l}\text { PLANT } \\
\text { HEIGHT } \\
(\mathrm{CM})\end{array}$ & $\begin{array}{l}\text { NO OF } \\
\text { BRANCHE } \\
\mathrm{S}\end{array}$ & $\begin{array}{l}\text { LEAF } \\
\text { AREA } \\
\left(\mathrm{cm}^{2}\right)\end{array}$ & $\begin{array}{l}\text { FRUIT } \\
\text { LENGTH } \\
(\mathrm{cm})\end{array}$ & $\begin{array}{l}\text { FRUIT } \\
\text { BREADTH } \\
(\mathrm{cm})\end{array}$ & $\begin{array}{l}\text { NO OF } \\
\text { FRUIT } \\
\text { PER } \\
\text { PLANT }\end{array}$ & $\begin{array}{l}\text { FRUIT } \\
\text { YIELD kg/ha }\end{array}$ \\
\hline Bird pepper & 35.3 & 17.11 & 11.6 & 23.4 & 2.05 & 0.65 & 75 & 2239.99 \\
Thai pepper & 26.8 & 14.30 & 5.5 & 23.6 & 2.65 & 1.18 & 4.2 & 1520.00 \\
Bell pepper & 23.9 & 12.20 & 6.2 & 25.8 & 7.24 & 4.54 & 36 & 1680.00 \\
Tabasco pepper & 28.4 & 15.25 & 21.8 & 27.8 & 9.04 & 1.65 & 40 & 2426.60 \\
Hebanero pepper & 26.2 & 18.72 & 10.3 & 28.2 & 2.76 & 3.05 & 44 & 1906.66 \\
\hline Mean & $\mathbf{2 8 . 1 2}$ & $\mathbf{1 5 . 4 3 6}$ & $\mathbf{1 1 . 0 8}$ & $\mathbf{2 7 . 7 6}$ & $\mathbf{4 . 7 5}$ & $\mathbf{2 . 2 1}$ & $\mathbf{4 7 . 4}$ & $\mathbf{1 9 5 4 . 6 5}$ \\
SEM & $\mathbf{1 . 7 3}$ & $\mathbf{0 . 9 5}$ & $\mathbf{2 . 9 1}$ & $\mathbf{2 . 4 5}$ & $\mathbf{1 . 2 7}$ & $\mathbf{0 . 6 3}$ & $\mathbf{3 . 3 0}$ & $\mathbf{1 6 8 . 9 3}$ \\
LSD (P = $\mathbf{0 . 0 5})$ & NS & $\mathbf{2 . 3 8}$ & $\mathbf{4 . 3 9}$ & NS & $\mathbf{1 . 1 9}$ & $\mathbf{2 . 1 5}$ & $\mathbf{2 . 6 5}$ & $\mathbf{3 2 . 2 7 2}$ \\
\hline
\end{tabular}


TABLE 2: CORRELATION MATRIX BETWEEN YIELD COMPONENTS AND FRUIT YIELD

\begin{tabular}{|c|c|c|c|c|c|c|c|c|}
\hline DAYS TO $50 \%$ & $\begin{array}{l}\text { DAYS TO } \\
50 \% \\
\text { FLOWERING }\end{array}$ & $\begin{array}{l}\text { FRUIT } \\
\text { BREADTH }\end{array}$ & $\begin{array}{l}\text { FRUIT } \\
\text { LENGTH }\end{array}$ & $\begin{array}{l}\text { LEAF } \\
\text { AREA }\end{array}$ & $\begin{array}{l}\text { NO OF } \\
\text { BRANCHE } \\
\text { S }\end{array}$ & $\begin{array}{l}\text { NO OF } \\
\text { FRUIT PER } \\
\text { PLANT }\end{array}$ & $\begin{array}{l}\text { PLANT } \\
\text { HIEGTH }\end{array}$ & YIELD \\
\hline $\begin{array}{l}\text { DAYS TO 50\% } \\
\text { FLOWERING }\end{array}$ & $1.000^{* *}$ & & & & & & & \\
\hline FRUIT BREADTH & -0.786 & $1.000^{* *}$ & & & & & & \\
\hline FRUIT LENGTH & -0.403 & $0.405^{*}$ & $1.000^{\star *}$ & & & & & \\
\hline LEAF AREA & -0.356 & 0.396 & -0.064 & $1.000^{* *}$ & & & & \\
\hline $\begin{array}{l}\text { NO OF } \\
\text { BRANCHES }\end{array}$ & 0.320 & -0.318 & $0.551^{*}$ & 0.143 & $1.000^{\star *}$ & & & \\
\hline $\begin{array}{l}\text { NO OF FRUIT } \\
\text { PER PLANT }\end{array}$ & 0.948 & -0.634 & -0.585 & -0.290 & 0.057 & $1.000^{\star *}$ & & \\
\hline PLANT HEIGTH & 0.478 & -0.385 & -0.548 & 0.619 & 0.280 & 0.502 & $1.000^{* *}$ & \\
\hline YIELD & $0.613^{*}$ & -0.395 & $0.329^{*}$ & 0.067 & $0.913^{\star *}$ & $0.422^{*}$ & $0.424^{*}$ & $1.000^{\star \star}$ \\
\hline
\end{tabular}

Keys: ${ }^{*}$ significant at $5 \%$ level; ${ }^{* *}$ significant at $1 \%$ level.

\section{REFERENCES}

Agusiobo, O. N., 2002. Vegetable Gardening. Macmillan Education Publication, Ibadan, PP 65

Aliyu, L., 2000. The Effect of Organic and Mineral Fertilizer on Yield and Composition of Pepper (Capsicum Annum L.), Biology of Agriculture and Horticulture 18:29-36.

Amadi, C. O., Ene - Obong, E. E and Okocha P. I., 2008. Yield and Yield Attributes of Potato Grown Under Supra - Optimal Ambient Temperatures. In Proc. $32^{\text {nd }}$ Annual conference of Genetic society of Nigeria, held at Usman Danfodiyo University, Sokoto, $9^{\text {th }}-12^{\text {th }}$ November, 2008. Pp $10-18$

Dagnoko, S., Yaro - Diarisson. N., Sanogo, P. N., 2013. Overview of Pepper (Capsicum Species)Breeding in West Africa. African Journal of Agricultural Research. 8, (13):1108-1114.

Dewitt. D., and Bosland, P. W., 2009. Complete Chilli Pepper Book. A Gardens Guide to Choosing Growing, Preserving and Cooking. Timper Press. PP 1-2.

F. A. O. 2005 Annual Report. Food and Agriculture Organization Database. pp $10-15$

Ganeshreddy, M., Kumar, H. A., Salimath, P., 2008 Correlation and Path Analysis in Chilli. Karnatha Journal of Agricultural Science. 21, (3): 428-430.

Grubben, G. J., 1997 Tropical Vegetables and their Genetic Resources. IPRGR, Rome, Italy PP. 197.

Honya, K., 1981 Studies on the Improvement of Rice Plant Cultivation in Volcanic Ash Paddy Field in
Tohoku District. Tohoku Agricultural Experiment Station. Bulletin21: 1 - 143.

Hosamani, R. M., and Shinkumar 2008. Correlation and Path Analysis in Chili. Indian Journal of Horticulture 65:349-352.

Idowu, A. A., Agida, O. O., Ogunniyan, D. J. and Ajayi, E. O., 2012. Flowering and Fruiting Behaviour of Long Cayenne Pepper (Capsicum Frutescen L). International Journal of Plant Breeding Genetics. 15, (4): 228-237.

Islam K. M. A, Islam A. K. A, Rasul M. G, Sultana N. and Mian. M. A. J., 2008.Genetic variability and character association in ginger. Annals of Bangladesh Agriculture, 12, (1):1-12

Iwo, G. A and Ekaette, E. A., 2010. Genetic component analysis of yield related traits in some ginger genotypes. Nigeria journal of Genetics. (23):8185.

Kehinro, O. O. and Ketiku, O. A., 2004. Contribution of Tropical Chilliea as Ascorbic Acid Composition. Food Chemistry 11:43-49.

Murat, T. and Vehdettin, C., 2004. Relationships Among Triats Using Correlation and Path Coefficient Analysis in Safflower (Carthamus tinctorius L.). Shown at Different Fertilization Level and Row Spacing. Asian Journal of Plant Science 3 (6): 683-686.

Singh, R. K., and Chandhary, B. D., 1985. Biometrical Methods in Quantitative Genetics Analysis Kalyani Publishers, New Delhi.

Udoh, D. J., Ndon, B. A., Asuquo, P. E. and Ndaeyo, N. U., 2005. Crop Production Techniques for the Tropics Concept Publication. Lagos, Nigeria P.446. 